\title{
Country Specifics of a Universal Right?
}

\author{
Freedom of political speech in the Slovak Republic
}

\section{Max Steuer}

Max Steuer, 21, is currently an MA candidate in International Relations and European Studies at Central European University in Budapest. In 2014, he obtained an undergraduate degree in Political Science from Comenius University in Bratislava with a thesis titled Freedom of Speech Under Pressure? Analysing Judicial Decisions and Political Discourse in Slovakia'. Apart from human, especially political rights, he is interested in the political systems of the Slovak and Czech Republics with an emphasis of the role of constitutional courts in these countries, and in the concepts of democracy, legitimacy, constitutionalism and rule of law in context of European integration. His e-mail is steuer1 [at]uniba.sk.

\begin{abstract}
This paper tests the assumption of a universal right to freedom of speech in the context of the Slovak Republic, a Central European country still facing the legacies of suppression of freedom of speech during the communist regime, in order to find out whether the conception of free speech understood as European is used in Slovakia as well. Firstly, it examines key theories of freedom of speech both in the Anglo-American and Central European scholarship with emphasis on the reflections of 'Western' ideas in post-communist philosophical, legal and political thought. Secondly, it utilizes simple statistical methods to analyse the outcomes of judicial decision-making concerning issues of political speech in Slovakia according to the incidence of theoretical justifications of freedom of speech. The results indicate that the Slovak (and as some indicators show, also Central European) approach to freedom of speech differs from the one viewed as 'European' in some respects.
\end{abstract}

Keywords: European Court of Human Rights, freedom of speech, judicial decision-making, political discourse, philosophical and theoretical justifications, Slovak Republic, theories of freedom of speech 


\section{Introduction}

In the $17^{\text {th }}$ century, long before major international human rights declarations, conventions and constitutions of democratic states, the well-known Dutch philosopher Benedict de Spinoza (1670) remarked that 'It is far from possible to impose uniformity of speech, for the more rulers strive to curtail freedom of speech, the more obstinately are they resisted; not indeed by the avaricious [...], but by those whom good education, sound morality, and virtue have rendered more free.' Spinoza's requirement of a possibility to express various, even conflicting opinions among the people in the public sphere anticipated one of the key ideas of vibrant civil society, that was about to be formed in democratic countries. The view of the right to freedom of speech (expression) ${ }^{15}$ as one of, if not the most important individual rights, was enhanced by its incorporation into the Article 19 of the Universal Declaration of Human Rights (below: Declaration) as follows: 'Everyone has the right to freedom of opinion and expression; this right includes freedom to hold opinions without interference and to seek, receive and impart information and ideas through any media and regardless of frontiers.' Soon, other documents which encompassed freedom of speech followed; the International Covenant on Civil and Political Rights (below: Covenant) and, in Europe, the European Convention on Human Rights (below: Convention). The latter plays an especially crucial role in safeguarding of (not only) the right to freedom of speech in this region, as it creates a largely effective oversight system that is voluntarily accepted by the participating states (Donnelly 2003: 138-141). The influence of the Declaration on the development of these legally binding mechanisms shall not be neglected, though, as it has been at the heart of demands made by peoples and individuals around the world that their rights be respected and protected' (Clapham 2007: 42). For freedom of speech, this is ultimately true, despite some objections towards the Declaration as a whole, according to which it focused too much on civil and political rights and paid not enough attention to economic, social and cultural rights (e.g. Darraj 2010: 99). In other words, the positive influence of the Declaration on spreading of standards for freedom of speech is not affected by this 'Western ideals' criticism and the right itself, therefore, can be viewed as standing in the heart of individual political rights without which it would not be possible to live in democratic political regimes anywhere in the world.

\footnotetext{
15 The term 'freedom of expression' is used in more often than 'freedom of speech' in the overview of major human rights documents. However, as my paper concentrates mostly on one specific kind of expressions - political speeches - I consider more proper to use the term 'freedom of speech' throughout the text.
} 
The key position of freedom of speech in a democracy is, in my view, essential for analysing its scope, protection and examples of violation in either state that declares its commitment to this form of government. In my paper, I start with a more detailed account of these and similar arguments from a theoretical point of view, in order to justify the role of theory of freedom of speech at recognition and entrenchment of this right in legally binding acts, especially the democratic constitutions. Then, I provide an overview of scholarship about freedom of speech with emphasis on Central Europe (and within it to Slovakia, the Czech Republic and Hungary), where I seek for similarities and differences between the global understanding of freedom of speech and its view in these countries. Furthermore, I explain the methodology of an empirical analysis based on examination of philosophical and theoretical (below: $\mathrm{PH}-\mathrm{T}$ ) justifications of freedom of speech in Slovak judicial decisions in cases concerning conflicts between freedom of speech and personal rights (the protection of personality). Finally, the results of the analysis will be presented, which answer the question, what role do philosophical and theoretical justifications of freedom of speech play in reasoning of Slovak courts in the analysed type of cases. The results of this case study allow formulating some assumptions about the whole region possible to be tested via further research, including the one that the approach to freedom of speech in Central Europe differs from the 'universal' one encompassed in the Declaration, constructed mostly on a careful account of theoretical justifications of freedom of speech.

\section{Theories of freedom of speech: what are they and why are they important}

Before turning to the review of free speech scholarship, which is carried out on the basis of distinguishing between philosophical and legal approaches to the phenomenon, some introductory arguments about the theory of freedom of speech may be useful to provide. Firstly, freedom of speech as a political right emerged predominantly as a result of rather philosophical theories put forward by influential political thinkers, such as Baruch Spinoza and John Stuart Mill. ${ }^{16}$ Specifically, in the era of enlightenment freedom of speech became essential for progress in societies, as it is manifested in Article 11 of the Declaration of the Rights of Man and of the Citizen. ${ }^{17}$ Later, the provision of the First Amendment in the US Constitution ${ }^{18}$ laid down the

\footnotetext{
16 This is not to say that all philosophers have been supporting freedom of speech. In fact, from the ancient times, a well-known position to the issue was that of Plato (2006: 91-92), according to whom a strict regulation of various forms of expressions would be necessary in an ideal society.

17 'The free communication of ideas and opinions is one of the most precious of the rights of man. Every citizen may, accordingly, speak, write, and print with freedom, but shall be responsible for such abuses of this freedom as shall be defined by law.'

18 'Congress shall make no law respecting an establishment of religion, or prohibiting the free exercise thereof; or abridging the freedom of speech, or of the press; or the right of the people peaceably to assemble, and to petition the Government for a redress of grievances.'
} 
pattern for safeguarding freedom of speech in democracies. This short historical excursion demonstrates that a philosophical discussion about freedom of speech was present long before any legal guarantees of this fundamental right.

Secondly, by legal proceedings in which freedom of speech is at stake, it is impossible to set firm borders between legal and philosophical arguments (Barendt 2005: 2-6). A legal interpretation of the scope of freedom of speech, as well as other human rights, is in fact limited by the text of the Constitution and legislation of the state concerned. These limits, however, offer only a general framework, which requires legal interpretation by courts. ${ }^{19}$ By such interpretations, philosophical arguments derived from theories of free speech play an important role, as they summarize the reasons and principles which stand behind the legal protection of the right. For instance, in one of its precedential cases called Handyside v. the United Kingdom, the European Court of Human Rights (below: ECtHR) expressed, that 'Freedom of expression constitutes one of the essential foundations of such a society, one of the basic conditions for its progress and for the development of every man'. It acknowledged freedom of speech as important because of its role in a democracy and for the self-fulfilment of an individual. Such a thought builds directly on some premises included in the theories of freedom of speech.

Thirdly, the term 'theories of freedom of speech' raises some concern about its clarity as it is not exactly determined what should be included under its scope. The best approach in my view is to concentrate on different justifications that support freedom of speech (such as the argument of searching for truth, self-fulfilment of an individual or democratic participation which I mention below). These arguments create a convincing reasoning for freedom of speech if we consider them as various philosophical views on the role of free speech in the society which often overlap or complement each other (Bartoň 2010: 26). A search for these arguments in legal provisions and documents, such as the decisions of courts, does not mean that the right to freedom of speech is violated in the moment when one of these arguments is not applied, as for some types of speeches some arguments are more relevant than others. For political speech, for instance, it

\footnotetext{
${ }^{19}$ On the one hand, courts are 'the appropriate bodies to adjudicate disputes as to the content of [those] rights and their application to concrete situations' (Christie 2011: 3). They must interpret constitutional freedom of speech provisions in accordance with 'the text of the constitution as a whole', national principles and precedents and decisions of international courts and tribunals (Barendt 2013: 892-3). On the other hand, legal rules are binding also for courts and they determine the outcome of their verdicts. As a result, the judges of these courts may not become 'philosopher kings' because although they often incorporate their views about ideal society into their decisions (and decisions in free speech cases exceptionally allow to do that), the public can itself judge these decisions and criticize them (Christie 2011).

The relationship between legal provisions and courts' decision-making in free speech cases points out the specific position of interpretation and argumentation in favor of or in opposition to freedom of speech. For more on this issue, see also Steuer (forthcoming).
} 
is more plausible to argue that the importance of such speech lies in the possibility of participation of citizens within a democratic regime, than to view political speech as a way of self-fulfilment of an individual (this justification is mostly used by speeches connected to artworks or culture). Naturally, this approach to theories of freedom of speech is not the only one, as we will see from the state of the art below. Some theorists prefer to deal with theories of freedom of speech when they place this right into context of other rights (e.g. Smolla 1992). Others use the term to identify different perspectives that can be applied by concrete speeches (Scanlon 2003). Either approach we apply, the classic philosophical justifications seem to remain at the core of these theories, as it would be impossible to discuss the actors, perspectives or relationships connected to freedom of speech without understanding, why is it an essential individual right.

In sum, theories of freedom of speech are built of arguments which justify the importance and reasons for protection of this fundamental right. Their practical understanding and applying in concrete legal cases where freedom of speech is involved strengthens the link between them and the current legal provisions which can also be derived from the philosophical theories of freedom of speech.

\section{Approaches to freedom of speech in the world and Central Europe: State of the $\mathrm{Art}^{20}$}

Freedom of speech allows for a variety of different interpretations, which may be divided into two groups: (1) interpretations of free speech as a philosophical and theoretical issue, (2) analyses of legal protection, guarantees or case law concerned with the right to freedom of speech. We may apply this division criterion also to the literature available but a further difference should be emphasized: whether the source relates only to the US context of free speech or it takes into account also the European tradition.

\section{Philosophical approaches to freedom of speech in the world and in Central Europe}

Chronologically, the most important philosophical defence of freedom of speech is that of J.S. Mill (2009 [1859]). Although there were works which mentioned free speech before Mill (such as that of John Milton), 'Mill's argument is more than just one amongst other, equally influential arguments. It really is the classic version of the classic defence' (Haworth 2002: 7). Mill's arguments that 'the opinion which it is attempted to suppress by authority may possibly be true'

\footnotetext{
${ }^{20}$ See also Steuer (2014a).
} 
(Mill 2009 [1859]: 29) and 'however true [an opinion - M.S.] may be, if it is not fully, frequently and fearlessly discussed, it will be held as a dead dogma, not a living truth' (ibid.: 58-59), influenced a range of, especially US, scholars such as Scanlon (2003), O’Rourke (2001) or Smolla (1992). Some US theorists prefer the so-called 'marketplace metaphor', which is a modification of Mill's argument by Supreme Court Justice O. W. Holmes. As Smolla (1992: 8) notes, 'for Holmes, the benefit of the marketplace was not the end but the quest, not the market's capacity to arrive at final and ultimate truth but rather the integrity of the process. The value of the market was its capacity to provide 'the best test for truth". This rationale can better stress the 'preferred position' of free speech than 'general theories of free speech', to which belong absolutism, bistoricism and balancing (ibid.: 23-42). The problem with this argument is, as is noted in overviews of free speech issues (e.g. Barendt 2005: 12-13), that the free market does not have to see truth as the highest value and therefore its role in providing the 'test for truth' is undermined.

It should be noted here, that a negative attitude to marketplace metaphor could be influenced by the author's personal view on the issue of market regulation. Leaving all opinions to be judged at a fully unregulated market is, in my view, associated with a strictly libertarian position, although the content of such a position is sometimes unclear. For instance, Heyman (2008: 27) differentiates between 'libertarian and modern view' on free speech and associates all the wellknown arguments (pursuit of truth, democratic self-government, and individual liberty) with the 'classical libertarian traditions of Locke, Cato, Jefferson and Madison'. In his opinion, this tradition linked individual rights to societal interests, while today the individuality of these rights plays a primary role (at least in the US tradition - M.S.). Paradoxically, then, the modern view is closer to the usual understanding of the 'libertarian' position than the classical view explained by this term. In my opinion, however, it would be more appropriate to use the word 'liberal' with the classical tradition and not to seek to make sharp distinctions with the modern understanding. After all, in many countries including those in Central Europe, the 'free speech tradition' is much younger than in the United States.

Other philosophical and theoretical sources stick to the arguments of J.S. Mill. For instance, O'Rourke (2001: 159-163) sees the value of Mill's arguments in the importance of 'the discovery of truth for the sake of individuality', that is a necessary condition for truth being 'desirable for the progress of society'. O’Rourke therefore criticizes another philosopher, Alan Haworth (2001) who acknowledges John Milton as the author of the original free speech defence. Apart from these 'authorship' issues, Haworth also introduces four criteria that are necessary for an argument to fall under the protection of free speech. The author summarizes them in this way. 
An argument [...] '(i) must identify a class of acts and argue for their legal protection; (ii) that they must be speech acts; (iii) that they must treat the right to free speech as a public right; (iv) that they must treat it as a component in a wider, liberal, value system' (Haworth 2002: 10, 221-222). He views 'political material addressed to a wider public' as the most accurate type of speech that fulfils all these criteria and therefore demands protection.

The 'Millian principle', which allows restrictions to free speech only 'to prevent harms to others', is the starting point also for Scanlon's (quite complex) theory of freedom of speech (expression) (2003: 6-25). In Scanlon's view, the Millian Principle sets the limits of restrictions of free speech (or 'acts of expression', as he calls speech) and within this principle 'governmental policies [...] are subject to justification and criticism on a number of diverse grounds' (ibid.: 22-23). Another benefit of this theory lies in distinguishing the interests of different kinds of actors (participant, audience, bystander) in protection of free speech (ibid.: 85-92), and in acceptance of the existence of different categories of speech that allow for different rules for restriction. Scanlon's theory is sometimes criticized; e.g. by Haworth (2002: 219), who points out to an inconsistency: Scanlon attempts 'to support a 'Millian' principle with a roughly Rawlsian argument'. This relates to the difference between utilitarianism (or consequentialism of which Mill is usually referenced as a supporter) and contractualism, but it is not necessary for us to examine this in greater detail now. All in all, this theory remains influential and quite consistent because of its applicability also in modern world.

Naturally, almost no Anglo-American scholar (including those who form theories of freedom of speech) supports the idea of absolutely unregulated speech. Heyman (2008: 32-33) lists three reasons why an absolutist position is dangerous: (1) the inability to distinguish between 'legitimate and illegitimate restrictions' makes opposing the latter ones more complicated, (2) free speech absolutism leads to 'sacrificing other individual rights' which also deserve protection, (3) 'an excessive defense of First Amendment freedoms may weaken the legitimacy - and thus the public acceptance - of the very rights it means to defend.' The author therefore develops an own 'theory of the First Amendment', which he calls a 'liberal humanist' theory. This theory, which unifies the values of liberty (part of which is free speech) and dignity, forms a contribution to the discussion by stressing the fact, that rather than searching for conflicts of rights, we should identify their common characteristics, which allow for protecting both of them.

The presented overview deals only with selected aspects of philosophy and theory of free speech. Warburton (2009) offers a popular introduction which covers these aspects and a number of complicated issues today (but deals less with the problem of political speech). 
Bahgwat (2012) introduces a 'structural understanding of the Bill of Rights' and especially freedom of speech, according to which '[the Bill of Rights is] not generally intended to protect individual liberty, but rather to organize and place limits upon government' (ibid.: 79). Classic free speech arguments are reflected also in political science, for instance in Dahl's theory of polyarchy (Dahl 1989). Even a Marxist theory of free speech was developed in recent times (Roberts 2003), although its application in society today is doubtful. Some authors critically assess the changing approach to free speech values in US society after 2001 and declare, that 'arguments for free speech must be made. Otherwise, it all comes down to who hollers loudest' (Levinson 2003: 18). Because of the changing trends, many discussions are being opened in both academic and popular level (e.g. the discussion between Sunstein and Levendosky in Egendorf (2003)). The range of English sources indicates the utmost importance of free speech issues in the USA and - to a lesser extent - in Britain.

When, however, searching for philosophical and theoretical sources in the European scholarship (and especially in Central Europe), it is not easy to find a complex philosophical interpretation either. As professor Višňovský (2013: 444-445) emphasizes, Mill's liberal approach misses, except from some traditions from the First Czechoslovak Republic, a broader articulation of its ideas and attitudes in the public. This is true as even the most complex monographs (of Czech authors) focus on the legal application of free speech provisions and mention philosophical problems only in some minor cases or at the beginning of their explanation (see Barton 2010, Herczeg 2004, Jäger and Molek 2007). Petrík (2004) wrote an article about the liberal theory of free speech' which is, however, a less significant theory which stresses the importance of the place where the speech is being carried out (i.e. on whose property). This is definitely not a liberal theory as it is understood by leading US scholars. To some extent, the general theory is applicable to Central Europe, but any conception of free speech in this environment needs to deal with 'the combination of freedom and responsibility in European understanding', as opposed to the US one (Smolla 1992: 354). A theory of free speech for postcommunist countries is yet to be developed. ${ }^{21}$

\section{Legal approaches to freedom of speech in the world and in Central Europe}

Among the second group of interpretations of free speech and studies which deal with it from a legal perspective, the prevalence of Anglo-American literature is also more than noticeable. As a legal concept, the scope and protection of freedom of speech is a concern of constitutional law.

\footnotetext{
${ }^{21}$ Obviously, some signs of such a theory are visible in the publications already written in the Czech Republic and it cannot be excluded, that something was already published but is not well known yet.
} 
However, identifying a value or set of values underlying any single constitutional system of freedom of expression is likely to be difficult' (Stone 2011: 416). In the same study, Stone (2011: 417) also notes the difficulty to study free speech comparatively because of the specific 'legal and political culture' of the country observed. The US constitution gives freedom of speech a privileged status in the First Amendment that is examined in many legal studies. However, the Amendment is not immune to changes in time. According to Sunstein, 'the law now faces new constitutional problems', which require an 'ambitious reinterpretation of the principle of free expression' (1993: 16). However, for those who do not need to study precisely the case law of the USA, the complex examination of different legal approaches in the US, Britain, Australia, Canada and the ECtHR provided by Barendt (2005) is perhaps the most comprehensible source available. Apart from other problems, Barendt (2005: 154-197) devoted a chapter also to political speech which he classifies as seditious speech, group libel, blasphemy laws and official secret laws. As we may see from this classification, more relevant for this paper is the next chapter in Barendt's monograph called 'Libel and Invasion of Privacy' (2005: 198-246), where he deals also with initiation of actions by politicians. However, it is hard to understand, why he does not qualify speech acts concerned with politicians as political speech. Nevertheless, the book offers many examples of judicial decisions that became precedential in the case law of a selected country or of the ECtHR.

The last category of sources relates to legal issues of freedom of speech in Central Europe. The offer here is richer than in philosophical issues, although it mostly consists of studies about specific problems. In Slovakia, it includes law commentaries to Article 26 of the Slovak Constitution, dealing with freedom of speech, and relevant provisions (Bröstl 2010, Drgonec 1999, 2012, Svák and Cibulka 2013) or selected decisions of the ECtHR (Svák 2011).

This category also covers legal analyses of selected issues connected to freedom of speech, such as non-pecuniary damages in actions for protection of personality (Wilfling and Kováčechová 2011), the highly discussed decision in the case of the journalist Tom Nicholson (Deák 2013a, 2013b), collection of judicial decisions of higher courts in defamation cases (Horváth and Budinská 2013), commented judicial decisions connected to media freedom (Kamenec 2013) or media policy in general (Školkay, Hong and Kutaš 2011) and a handbook for journalists (Kerecman 2009). A monograph from Czech author Ondřejek (2012) about the application of principle of proportionality is also beneficial for gaining theoretical knowledge about judicial decision-making. Recently, a monograph was published by the former judge of the Slovak Constitutional Court which concentrates on freedom of speech and compares its legal status 
with the European level, represented by the case law of the ECtHR. It critically assesses the level of freedom of speech in Slovakia and concludes that 'there is no clear conception of freedom of speech in Slovakia' (Drgonec 2013: 386). According to Drgonec, the most apparent deficits can be identified in the positive obligations of Slovakia to protect freedom of speech in specific situations on the one hand (here he is concerned mostly with media regulation), and in improper functioning of the media and public opinion which is mostly concerned with tabloid news rather that offering and receiving reliable and actual information on the other. ${ }^{22}$ The monograph forms a contribution to the knowledge of freedom of speech in Slovakia, but still, in the prevailing part it uses a legalistic, not interdisciplinary approach.

On the Central European level, sources which deal with freedom of speech in connection with overcoming the legacies of the communist regime deserve special attention. As András Sajó, the current judge of the ECtHR for Hungary notes, postcommunist countries still often do not recognize the role of freedom of speech for embodying democracy.

We can often hear opinions, according to which it is not possible to apply freedom of speech in its whole range because of the specific characteristics of the transitional period. Several people, including judges, refer to the low level of political culture when justifying the necessity of regulation of freedom of speech in the name of personal rights. (Sajó 2005: 126).

Moreover, Sajó - rightly - considers such interpretation of freedom of speech in times of transition as an exact opposite of what would be desired (2005: 128-132). In addition, if such view gains dominance, the public also loses its trust in the power of freedom of speech and becomes rather apathetic and uninterested in political matters. In my opinion, an example of such approach can be found in the scientific production of Sajó's country. The most complex assessment of freedom of speech in Hungary, a more than 800-pages long monograph of an expert on media issues (Koltay 2008), reaches the conclusion, that 'freedom of speech is an ideal, an unattainable mirage, which when we approach it, loses its shape, becomes blurry and disappears in the hot air in the summer' (ibid.: 705). Although the analysis of the phenomenon itself and specifically in Hungarian environment is very comprehensive, including the explanation of the ever more intensive conflict between freedom of speech and personal rights in modern societies, the position that 'sometimes freedom of speech has to bow its head before other interests (basic rights or constitutional values)' (ibid.: 695 et seq.) carries possibly dangerous signs of its extensive regulation.

\footnotetext{
${ }^{22}$ See more on the content and assessment of the publication in Steuer (2014b).
} 


\section{Research design of the empirical analysis}

While the analysis of scholarship, which in the area of philosophical approaches to freedom of speech showed the absence of a clear theoretical conception in Central Europe, comprised references from more countries, the upcoming empirical analysis of the application of $\mathrm{PH}-\mathrm{T}$ justifications of freedom of speech in judicial decisions provides a case study of one country, i.e. the Slovak Republic. This design strives to satisfy the necessity of testing the general finding on the theoretical level via simple statistical analysis.

\section{The choice for Slovakia}

The reasons for choosing Slovakia as the country of observation are two - one related to historical roots of freedom of speech in the country and the other to current criticism of lowering free speech standards here from both domestic and international sources. Although the former reason could be possibly applicable also for the Czech Republic, which formed together with Slovakia a common state for the major part of the $20^{\text {th }}$ century, and the latter one for Hungary, where significant lowering of press freedom were identified (see e.g. Freedom House 2013), Slovakia combines both of them and therefore is, in my opinion, the most proper country to start such an examination.

More exactly, the special historical roots of freedom of speech in Slovakia are connected to the traditions of the First Czechoslovak Republic and then the dissent against the oppressive communist regime. The democratic Constitution of the First Republic (1920) encapsulated freedom of speech in paragraph $117 .^{23}$ Although the formulation of the provision expressively limited the individual's right to express his/her opinions by 'the limits of law' without any further conditions or explanations of these limits, this did not undermine the view of the Constitution as a as a stabile pillar of democracy (Vojáček, Schelle 2007: 228) and provider of basic guarantees of freedom of speech. However, after the break-up of the First Republic caused mainly by the interventions of the Nazi Germany, freedom of speech lost all stable mechanisms of its protection for more than fifty years. An interesting detail connected to the drafting of the Declaration after World War II is that the only experts who asked for more restrictive formulations of freedom of expression, were of the Soviet Union and of Czechoslovakia (Morsink 1999: 67). Although these demands were (officially) connected to the limitations of

\footnotetext{
23 '1. Every person may within the limits of the law express his or her opinion by word, in writing, in print, by picture etc. 2. The same applies to legal persons within the limits of their competence. 3. No one shall suffer in the sphere of his work or employment for exercising this right' (italics M.S.).
} 
fascist and other speeches (ibid.), they indicate that freedom of speech in its Western understanding was not a priority for Czechoslovak leaders.

Soon, the communist uprising in 1948 led to the new regime, where the constitutional protection of freedom of speech was only a formality and the real situation an exact opposite. The real extent of freedom of speech was close to zero, which could be observed already at reading the first sentence of Article 28 of the Constitution of Czechoslovak Socialist Republic (Simons 1989: 148-149, italics M.S.): 'In accordance with the interests of the working people, freedom of expression in all fields of public life, including in particular freedom of speech and of the press, is guaranteed to all citizens.' After the so-called Helsinki Accords with the participation of socialist Czechoslovakia were signed, dissidents such as the Movement of Charter 77 began to stress the need for material freedom of speech. In their words, 'The right to freedom of expression, for example, guaranteed by Article 19 of the [Covenant], is in our case purely illusory. Tens of thousands of our citizens are prevented from working in their own fields for the sole reason that they hold views differing from official ones, and are discriminated against and harassed in all kinds of ways by the authorities and public organizations' (Manifesto 1977). The dissident movements were the clearest personification of the struggle for freedom of speech in this territory.

After 1989 and the short period of the Czechoslovak Federal Republic, freedom of speech was entrenched into the Charter of Fundamental Rights and Freedoms and later, short before the dissolution of Czechoslovakia, into Article 26 of the newly-created Slovak Constitution. In the Constitution, the conditions for legitimate restrictions of freedom of speech were stressed in a far more strict way than in the documents in former regimes, where the 'laws' or 'interests of working people' satisfied the need for regulation. Here, three cumulative conditions in accordance with international standards have to be fulfilled in order to restrict the freedom legitimately: (1) there has to be a law allowing such regulation, (2) the measure has to be necessary in a democratic society, (3) it has to follow a legitimate aim i.e. the protection of rights and freedoms of others, state security, public order, or public health and morals.

Still, some of these formulations are quite vague (see also Drgonec 1999), and therefore require specification by case-law of Slovak courts. This leads us to the second reason why Slovakia is a relevant case to examine, which is the current criticism of Slovak courts' judgments in the socalled proceedings on protection of personality according the Slovak Civil Code (e.g. Kamenec 2013). There is also an example of such criticism stemming from international organizations, specifically the OSCE Representative on Freedom of the Media (Mijatović 2013). Naturally, the 
presence of PH-T justifications in court's judgments is not the only relevant factor to determine the scope of freedom of speech in Slovakia. In fact, previous analyses showed interesting conclusions also in other areas, such as the referencing to legal standards or principle of proportionality (Malová and Steuer 2014, Steuer forthcoming). However, investigating the presence of PH-T arguments allows answering the research question of this paper, concerned with the approach to freedom of speech in Slovakia (and, to some extent, in Central Europe) from its theoretical point of view as a universal right.

\section{Data collection and analysis}

Three points are worth to be mentioned here to elucidate the process of collecting and analyzing empirical data. Firstly, the units of observation were 162 judgments of Slovak courts in proceedings on protection of personality. Each of these judgments included a verdict either in favor of freedom of speech (i.e. it upheld the right of the opponent and denied the claim of the applicant, who wanted to restrict freedom of speech in some way) or against it (in this situation, the claim of the applicant was approved and freedom of speech was limited e.g. in a requirement to apologize for previous statement or to pay a compensation to the applicant).

Secondly, the presence or absence of PH-T justifications was determined according to examination of the court's decision where the reasons for the judgment for or against freedom of speech were explained. If the court mentioned some philosophical views on freedom of speech (e.g. that it is necessary for searching of truth, a democratic regime or a free and open society), the judgment was labelled as containing PH-T justifications. If not, then it was placed into the opposite category of not including PH-T justifications.

Lastly, the correlation between the presence/absence of PH-T justifications (as the independent variable) and the verdicts in favour or against freedom of speech (as the dependent variable) was investigated with statistical measures (Phi coefficient). In addition to the statistical measures, examples of concrete decisions were cited in order to better clarify and explain the results.

\section{Results of the empirical analysis}

The majority of the 162 judicial decisions included in the sample did not use arguments which can be included into the category of PH-T justifications of freedom of speech. As can be inferred from Table 1, less than a third (53) of the decisions used these justifications in the reasoning of their verdict. By these decisions, the probability of a verdict in favour of freedom of speech was more than twice as high as by decisions which did not utilize PH-T justifications. 
However, almost a third of all decisions decided in favour of freedom of speech without referencing to $\mathrm{PH}-\mathrm{T}$ justifications, which means that they are far from necessary to be included in the argumentation in favour of freedom of speech in Slovak legal environment, although they can be helpful to such decision.

If we look at the statistical relationship between these two variables (Table 2), we see that although we can reject the null hypothesis stating there is no relationship between them, there is only a rather weak correlation between them (with Phi reaching the value of 0.19 on the interval from $0-$ no relationship, to 1 - full correlation). The mild positive relationship between the inclusion of some philosophical justifications and the decision in favour of freedom of speech is demonstrated also on Chart 1.

Table 1. Presence and absence of PH-T justifications in judicial decisions

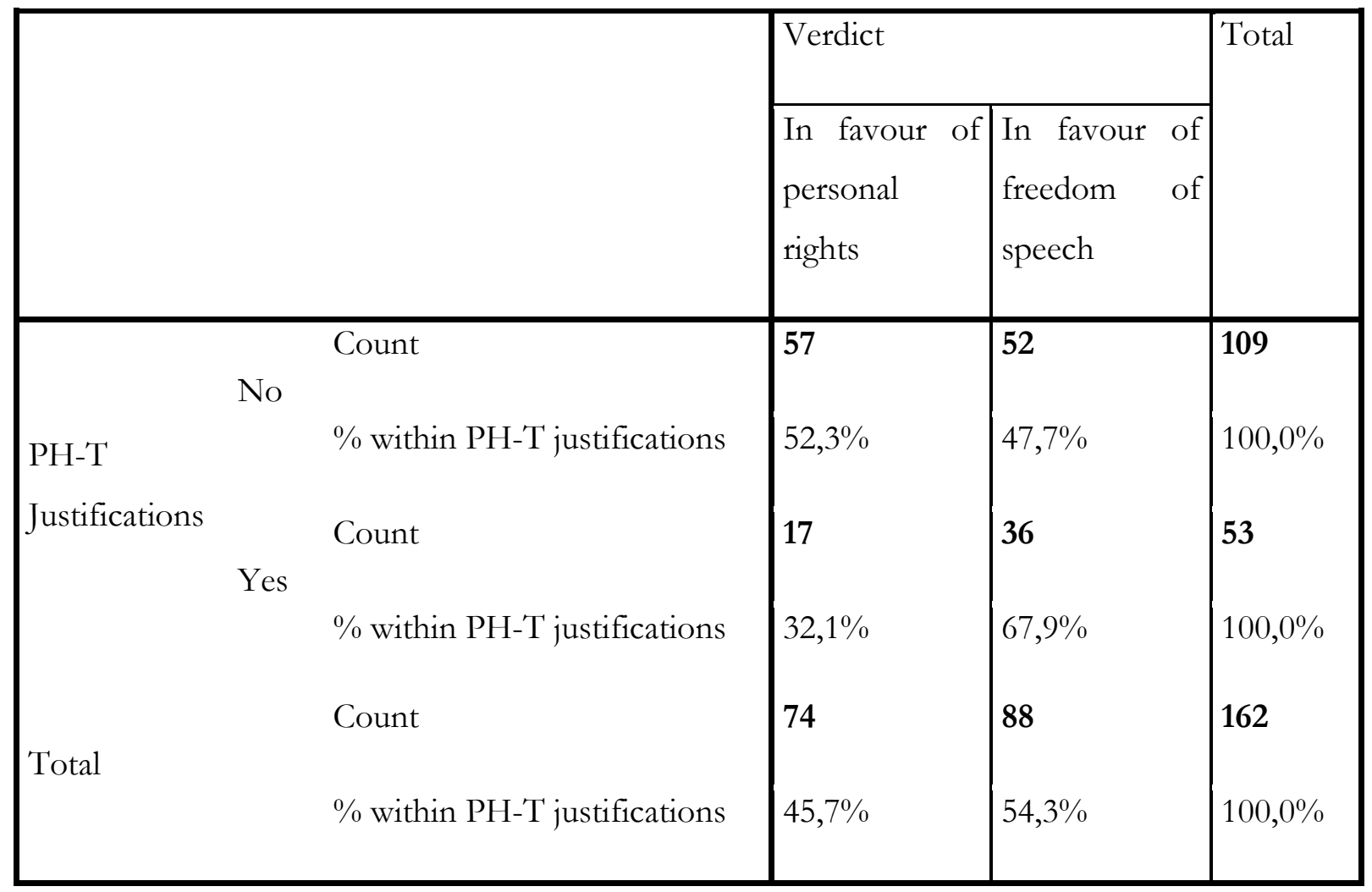

Source: Steuer (2014a). 
Table 2. Correlation coefficients for PH-T justifications

\begin{tabular}{|ll|l|l|}
\hline & & Value & Chi-Square Tests \\
& & & Approx. Sig. \\
\hline Nominal by Nominal & Phi & $\mathbf{, 1 9 0}$ & $\mathbf{, 0 1 5}$ \\
N of Valid Cases & &, 015 \\
\end{tabular}

Source: Steuer (2014a).

Chart 1. PH-T justifications and verdicts in favour v. against freedom of speech

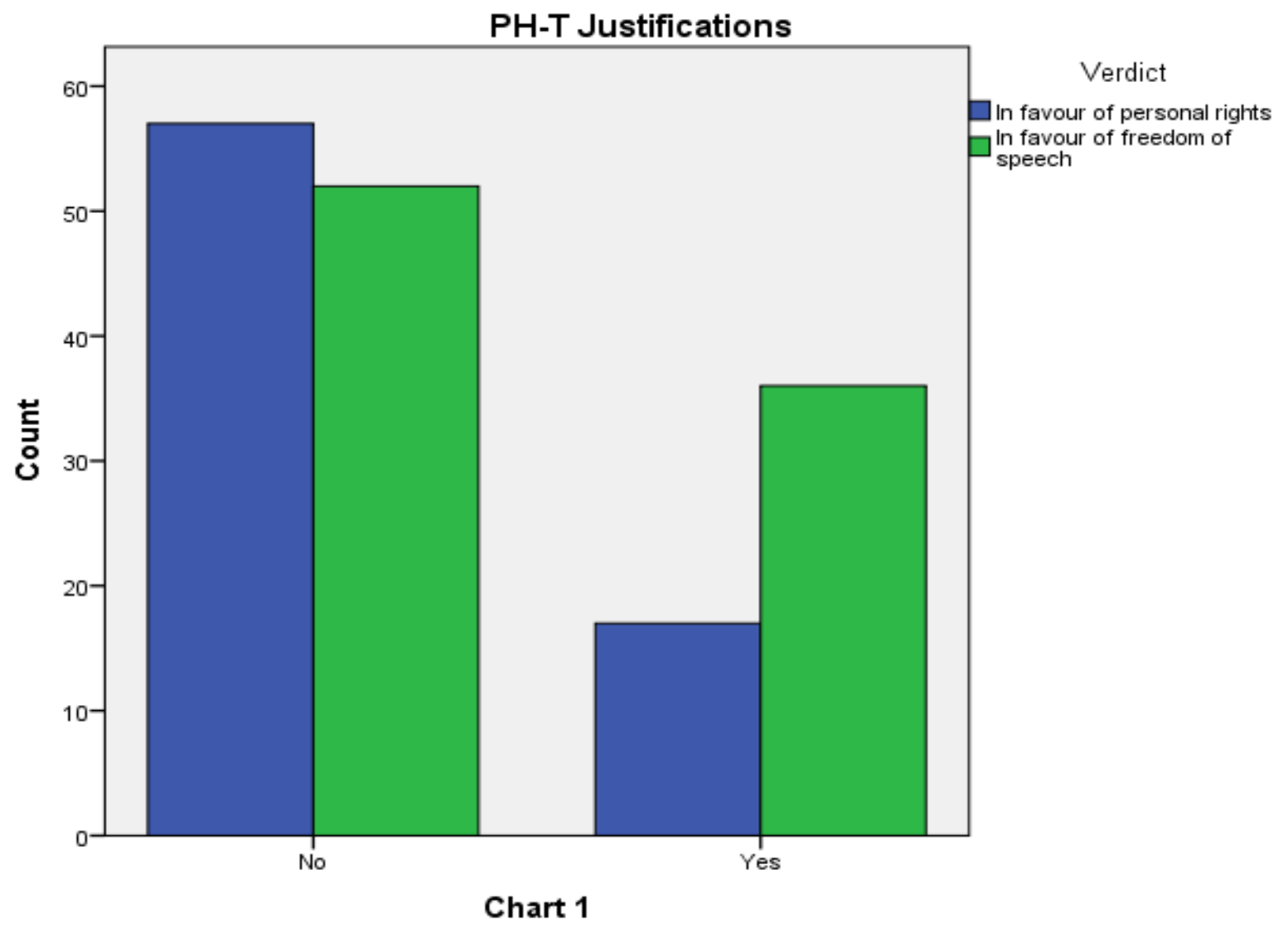

\section{Source: Steuer (2014a)}

How did the 53 decisions use PH-T justifications from a qualitative point of view? In cases which were decided in a way that limited freedom of speech despite such arguments, mostly only brief references to PH-T justifications in the wording of the case law of the ECtHR were mentioned without any own interpretation of the domestic court. What is more, the limits of 
freedom of speech were somehow stressed in the next sentences or sections. A typical example is the citation from a recent verdict in a dispute between a private person and the media: ${ }^{24}$

According to the case law of the ECtHR, which relates to the application of Article 10 of the Convention, the press plays an important role in a democratic society, and although it cannot exceeds some certain limits, including those for the protection of reputation of others, its task is to provide, in accordance with its duties and responsibilities, appropriate and reliable information and ideas on all matters of public interest [...] However, the right to freedom of speech is not absolute, it is limited as is stated in Article 10 Paragraph 2 of the Convention and Article 6 [sic!] Paragraph 4 of the Constitution, with rights to protection of personality to the extent specified in $\$$ 11 et seq. of the Civil Code (italics M.S.).

Naturally, some cases escape this rule of superficial argumentation with PH-T justifications in case of deciding against freedom of speech. This, however, does not have to mean, that the decision is well justified. An interesting example is the verdict of the District Court Prešov, ${ }^{25}$ which was formed after the annulment of the original verdict and returning the case to the district level by the regional court. In the first verdict, the court declined the application with detailed argumentation based on the test of proportionality and philosophical justifications. Some of these arguments were reproduced also in the 'corrected' decision, such as:

The court stated that freedom of speech is one of most important rights in a democratic society and includes freedom of opinions and freedom of receiving and dissemination of information. [...] [When basic rights standing on the same level conflict], the court has to carefully consider, taking into account the circumstances of each case, whether one right was not without any reason preferred before the rights of others. At the same time, it is necessary to respect certain specificities of normal investigative journalism, intended to inform the general public (in contrast to scientific publications, for example), which must, in particular with regard to the extent of individual contributions and the interests of the public, access to certain simplifications, and it cannot be argued that each simplification (or distortion) must necessarily lead to interference with the personal rights of the person concerned (italics M.S.).

\footnotetext{
${ }^{24}$ Regional Court in Bratislava, verdict 8Co/131/2013 from June 25, 2013. The case was concerned with publication of unclear information about the applicant being placed in a custody. See similar citations in decisions 6Co/112/2011 (Regional Court in Bratislava, verdict from April 16, 2012) or 12C/121/2007 (District Court Bratislava IV, verdict from June 19, 2012).

${ }^{25}$ Verdict 14C/259/2008 from October 26, 2011, confirmed by the verdict 18Co/25/2012 of the Regional Court in Prešov on January 16, 2013, which mostly only reproduced the arguments of the District Court. It is worth noting that the applicant was a judge.
} 
In contrast to this argumentation, with regard to the decision of the appellate court, the verdict limited freedom of speech. A particular attention deserves the reproduction of the appellate court's argumentation which misinterprets the case law of the $\mathrm{ECtHR}^{26}$ :

The appellate court [...] stated, that judges form a special category of natural persons which deserve even wider protection of their honour and dignity. This conclusion follows from Article 10, paragraph 2 of the Convention and enhances protection not only against interferences to the honour and dignity of an individual, but also to those governed against the authority and impartiality of the judicial power (italics M.S.).

In most of the 36 decisions in favour of freedom of speech which used PH-T justifications, a somewhat different approach can be observed. These decisions more often include their own interpretations of the philosophical value of freedom of speech in a democracy and do not stress its limits in the same section. In one of the oldest decisions included in the sample ${ }^{27}$, the District Court Bratislava V

[...] thought about the limits of freedom of speech which is one of the basic elements of a democratic society. Freedom of speech applies not only to information or ideas that are favourably received or regarded as inoffensive or unimportant, but also to those that are unpleasant, shock or raise concerns. So it is required for plurality and the spirit of openness, without which a democratic society is impossible. Freedom of speech is valuable for everyone.

There is only a minor number of decisions which used wider more complex justifications of freedom of speech based on its philosophical traditions. Such an approach was presented in several rulings of the Constitutional Court, beginning with the ruling II. ÚS 152/08, where the Court upheld the right to freedom of speech in connection to criticism of a judge. Some courts of lower instances were inspired by this argumentation and reproduced it in their decisions. If so, the decision was in favour of freedom of speech. An example of this is provided by the decision of the Appellate court in Trnava, ${ }^{28}$ which resolved a dispute between a regional politician and a regional newspaper, which reported about the politician's visit in a night club:

\footnotetext{
26 I was unable to get the original decision of the appellate court. However, the verdict from October 26, 2011 needed to be coded according to the presented methodology as a verdict which included all types of examined arguments and despite decided against freedom of speech. As some of the arguments in the 22-pages long decision conflict, it seems that the district court's judge decided contrary to his personal opinion, because he was bound by the legal opinion of the appellate court.

27 47Coch/3/2003, Verdict from September 13, 2005 in a dispute connected to information about the activities of the financial police. The court decided in favour of freedom of speech stating that 'the article itself did not deal with the applicant', who was a public figure.

${ }^{28}$ 24Co/252/2011, Verdict from July 18, 2012. Similarly the verdict of the Regional Court in Prešov 3Co/65/2012 from January 30, 2013 and Regional Court Nitra 25Co/108/2009 which among others states: 'For democracy, the dissemination of information, thoughts and opinions, either appraising, harmless or critical, shocking or concerning,
} 
The appellate court draws attention to relevant conclusions in the finding of the Constitutional Court, No. II. ÚS 152/08 from 15 December 2009, according to which the protection of freedom of speech is essential for several reasons. Freedom of speech is essential for democracy and for creation of free public opinion in an open society. It is also a tool for searching the truth, an instrument of competition and confrontation of different ideas and beliefs [compare Mill: On Liberty and also the dissent of Justice O. W. Holmes in the verdict of the Supreme Court in Abrams v. United States, 250 U. S. 616 (1919)].

Finally, freedom of speech can serve the goal of personal self-fulfilment usually in the form of various works of art. [...] A similar approach to the protection of freedom of speech is applied by the ECtHR, which arises from its constantly-cited case law. Freedom of expression constitutes one of the essential foundations of a democratic society and one of the basic conditions for its progress and for each individual's self-fulfilment. It is applicable not only to 'information' or 'ideas' that are favourably received or regarded as inoffensive or as a matter of indifference, but also to those that offend, shock or disturb.

The sample of decisions allows identifying several examples in which PH-T justifications were not connected to other detailed arguments in favour of freedom of speech (such as referencing to the respective articles of the Constitution and Convention) and despite the decision was made in favour of freedom of speech. Again, an older decision ${ }^{29}$ dealing with a dispute between a private person and a public figure about disseminating controversial information connected to ownership of property, offers an example of this kind, with the mention of quality of democracy as the most noticeable point:

The Charter of Fundamental Rights and Freedoms within freedom of speech and expression of ideas grants everyone the right to criticism. Criticism as part of freedom of speech is an important instrument determining the level and quality of democracy in the society. The exercise of the right to criticism is one of the important prerequisites for creating the atmosphere of critical society, fulfilling the need for confrontation of opinions, for the intransigence to negative social phenomena, i.e. for a versatile free development of the society.

Based on the abovementioned statistical data and examples it may be concluded, that although PH-T justifications do not enjoy a strong tradition in the case law of Slovak courts, if they are applied properly, not only mechanically reproduced to give the verdict a 'better appearance', they have a potential to provide a convincing argumentation line in favour of freedom of speech. The

is a vital necessity, for the public to be supplied by all important facts which are necessary to produce a debate about matters of public interest of high quality and subsequently to form the opinions of individuals or to reach consensus in actions [...] Openness in relation to different opinions and critical views enriches the society, sufficient information help to break stereotypes in thinking and increase tolerance. Last but not least freedom of speech and information significantly contribute to personal growth of the individual in intellectual and personal way, which is also an interest of an open democratic society.'

29 39Coch/1/2002, Verdict of the District Court Bratislava V from 13 February 2006. 
recent practice of the Constitutional Court leads me to the assumption that the role of these justifications in the decisions will rise slightly in the future, although it would be quite naive to think that they will one day play a dominant role in the legalistic environment of courts' judgments. In addition, if they are not interpreted in accordance with their philosophical background, which is included already in their name, it is possible to place them into conflicting positions and use them as a tool to argue against their rationale.

\section{Conclusion}

Central Europe is not 'another Europe' any more, when it comes to terms of basic legal provisions guaranteeing freedom of speech. The protection system established by the Convention and the case law of the ECtHR has provided a legal framework worth to follow for national courts when they decide in cases concerning conflicts of freedom of speech and other fundamental rights (Steuer forthcoming). Nonetheless, this framework remains a distinct European one, where the legitimate conditions for restriction of the freedom are explicitly stated and (should be) applied in practice. This difference from other understandings of freedom of speech, especially the American one, does not mean, that the basic principle for free expressions set out in Article 19 of the Declaration is not respected in Europe; quite the contrary. The European approach is just another way how to reach and respect this universal principle.

In my paper I tried to shed some light on this approach by examining, firstly, the theoretical approaches and available scholarship about freedom of speech in comparative perspective, and, secondly, the empirical evidence for usage of theoretical justifications of freedom of speech in the decision making of Slovak courts. Methodologically, my research design strived to satisfy the ever-emphasized necessity to match theory to practice by showing, how philosophical discussions about a fundamental right can shape and influence the day-to-day practice of its protection.

Three conclusions may be drawn from the theoretical and empirical analysis which may be tested by further research. Firstly, although there are various ways how to grasp theories of freedom of speech, basically, its crucial elements comprise distinct philosophical justifications of the importance of free speech for searching for truth, development of an individual, suspicion of government in power and other crucial reasons which can be by no means omitted in a democratic political regime.

Secondly, from the perspective of such understanding of the theory, however, contemporary Slovak (and as some signs indicate, also Central European) scholarship does not provide a 
satisfactory arrangement explaining the theoretical origins and evolution of freedom of speech in the region, even though these origins were apparently present during the resistance against the communist regime, to mention just one example. ${ }^{30}$ As a consequence, the scope and quality of protection of the right is usually not evaluated according to the criteria put forward by theories of freedom of speech. Also, no alternative approaches to freedom of speech from a theoretical point of view have been introduced yet.

Finally, as the results of the empirical analysis demonstrate, the absence of the theoretical discussion about freedom of speech in Slovakia coincides with the lack of usage of PH-T justifications of freedom of speech in the reasoning of Slovak courts. It is true that sometimes they may be applied and that they encapsulate a potential for more detailed and precise justifications of courts' judgments. On the other hand, the lack of theoretical understanding of freedom of speech may lead also to misinterpretations of PH-T justifications and their improper application to support arguments for restricting freedom of speech, which they in reality oppose.

The differences in theoretical understanding of freedom of speech indicate that the Slovak (and as some signs show, also Central European) approach to freedom of speech is not the same like the one in Western Europe or in the USA. At least, it places less emphasis on discussing the origins and reasons for protection of this fundamental right. Even though there are no significant variations in the legal recognition of the right in Slovakia compared to Europe, represented by the Convention, some country specifics appear, like the concentration on legal interpretations of freedom of speech rather than a full understanding of its worth in a Millian manner. Whether the Slovak practice will converge with the European one or will differ even more in the future, remains to be seen, but the convergence option is more likely to happen because of the decision making of the ECtHR and the slowly emerging scholarly discourse about the right, often in response to controversial and highly tracked cases where freedom of speech was limited with unsatisfactory reasons for such restrictions.

\footnotetext{
${ }^{30}$ Legal analyses of freedom of speech as a constitutional right are much more widespread.
} 


\section{Bibliography ${ }^{31}$}

Bahgwat, Ashutosh (2010): The Myth of Rights: The Puropses and Limits of Constitutional Rights. Oxford: Oxford University Press.

Barendt, Erik (2013): 'Freedom of Expression'. In: Michel Rosenfeld and András Sajó (eds.) The Oxford Handbook of Comparative Constitutional Law. Oxford: Oxford University Press. pp. 891-908

Barendt, Erik (2005): Freedom of Speech. Oxford: Oxford University Press.

Bartoň, Michal (2010): Svoboda projevu: principy, garance, meze. Praha: Leges.

Bröstl, Alexander (et al.) (2010): Ústavné právo Slovenskej republiky. Plzeň: Vydavatelství a nakladatelství Aleš Čeněk.

Charter 77 (1977): 'Manifesto of Charter 77 - Czechoslovakia'. English translation accessible at: http://lcweb2.loc.gov/frd/cs/czechoslovakia/cs appnd.html

Christie, George. C. (2011): Philosopher Kings? The Adjudication of Conflicting Human Rights and Social Values. Oxford: Oxford: Oxford University Press.

Clapham, Andrew (2007): Human rights: A very short introduction. Oxford: Oxford University Press.

Dahl, Robert Alan (1989): Democracy and its Critics. New Haven: Yale University Press.

Darraj, Susan. Muaddi (2010): The Universal Declaration of Human Rights. New York: Chelsea House.

Deák, Marko (2013a): 'Gorila a test proporcionality. Zablúdil súd pri hl’adaní limitov práva na ochranu osobnosti? (1. čast')'. Justičná revue 65 (1), pp. 31-43.

Deák, Marko (2013b): 'Gorila a test proporcionality. Zablúdil súd pri hl'adaní limitov práva na ochranu osobnosti? (2. čast')'. Justičná revue, 65 (2), pp. 184-200.

Donnelly, Jack (2003): Universal human rights in theory and practice. Ithaca: Cornell University Press.

Drgonec, Ján (2013): Sloboda prejavu a sloboda po prejave. Šamorín: Heuréka.

Drgonec, Ján (2012): Ústava Slovenskej republiky: Komentár. Šamorín: Heuréka.

Drgonec, Ján (1999): Základné práva a slobody podla Ústavy Slovenskej republiky: Zvärok 2. Bratislava: Manz.

European Court of Human Rights (1976): 'Case of Handyside v. the United Kingdom'. Application no. 5493/72. Accessible at: http://hudoc.echr.coe.int/sites/eng/pages/search.aspx?i=001-57499

Freedom House (2013): 'Hungary'. Accessible at: http://freedomhouse.org/report/freedompress/2013/hungary\#.U7-0TLFvuig

31 All online sources cited as to 1 September 2014. 
Haworth, Alan (2002): Free Speech. London: Routledge.

Herczeg, Jiří (2004): Meze svobody projevu. Praha: Orac.

Heyman, Steven J. (2008): Free Speech and Human Dignity. New Haven, Yale University Press.

Horváth, Edmund and Lucia Budinská (2013): Ochrana osobnosti a nábrada nemajetkovej ujmy. Bratislava: Iuris Libri.

Jäger, Peter and Karel Molek (2007): Svoboda projevu. Demokracie, rovnost a svoboda slova. Praha: Auditorium.

Kamenec, Tomáš (2013): 'Media Freedom in Danger? Legal Analysis of Selected Factors in the Slovak Republic'. Bratislava: Fair-play Alliance. Accessible at: http://www.fairplay.sk/pdf/Kamenec Analyza EN.pdf

Kerecman, Peter (2009): Sloboda prejavu novinára a ochrana pred jej żneurìitím. Bratislava: Slovenský syndikát novinárov.

Koltay, András (2009): A szólásszabadság alapvonalai. Budapest: Századvég Kiadó.

Levendovsky, Charles (2003): 'Free Speech Must Remain Protected'. In: Laura K. Egendorf (ed.) Should there be limits to free speech? San Diego: Greenhaven Press. pp. 13-17.

Levinson, Nan (2003): Outspoken: Free Speech Stories. Berkeley: University of California Press.

Malová, Darina and Max Steuer (2014): 'Sloboda prejavu v Slovenskej republike. Analýza vybraných súdnych rozhodnutí'. Právník, 153 (4), pp. 309-325.

Mijatović, Dunja (2013): 'OSCE media freedom representative concerned about Slovak judiciary seeking high damage awards in defamation cases'. Vienna: OSCE. Accessible at: http://www.osce.org/fom/101240

Mill, John Stuart (2009): On Liberty. (n.p.): The Floating Press.

Morsink, Johannes (1999): The Universal Declaration of Human Rights: origins, drafting, and intent. Philadelphia: University of Pennsylvania Press.

Ondřejek, Pavel (2012): Princip proporcionality a jeho role prí interpretaci základnich práv a svobod. Praha: Leges.

O'Rourke, K. C. (2001): John Stuart Mill and Freedom of Expression: The genesis of a theory. London: Routledge.

Petrík, Matúš (2004): 'Liberálna teória slobody prejavu'. Justičná revue, 56 (8 - 9), pp. 867-873.

Plato (2006): Stát [The Republic]. Bratislava: Kalligram.

Roberts, John Michael (2003): The aesthetics of free speech: retbinking the public sphere. Houndmills: Palgrave Macmillan. 
Sajó, András (2005): A šólásszabadság kézikönyve. Budapest: MTA Állam és Jogtudományi Intézet.

Scanlon, T. M. (2003): The Difficulty of Tolerance: Essays in Political Philosophy. Cambridge, Cambridge University Press.

Simons, William B. (1980): The Constitutions of the Communist world. Alphen ann den Rijn: Sijthoff \& Noordhoff.

Školkay, Andrej, Mária Hong and Radoslav Kutaš (2011): 'Does media policy promote media freedom and independence? The case of Slovakia'. School of communication and media. Accessible at: http://www.mediadem.eliamep.gr/wp-content/uploads/2012/01/Slovakia.pdf

Smolla, Rodney A. (1992): Free Speech in an Open Society. New York: Knopf.

Spinoza, Benedict de (1670): A Theologico-Political Treatise. Accessible at: http://www.sacredtexts.com/phi/spinoza/treat/tpt28.htm

Steuer, Max (2014a): 'Freedom of Speech under Pressure? Analyzing Judicial Decisions and Political Discourse in Slovakia'. Unpublished bachelor thesis. Bratislava: Comenius University, Faculty of Philosophy.

Steuer, Max (2014b): 'Ján Drgonec: Sloboda prejavu a sloboda po prejave (Recenzia)'. Plzeň: Epolis.cz. Accessible at: http://www.e-polis.cz/recenze-knih/835-jan-drgonec-sloboda-prejavu-asloboda-po-prejave-recenzia.html

Steuer, Max (forthcoming): 'The role of the ECHR in Setting the Norms for Freedom of Speech: A Case Study of Slovakia'. In: From Human Wrongs to Human Rights: Challenges for Contemporary Human Rights Law [Conference proceeding]. Toruń: UMK.

Stone, Adrienne (2011): 'The comparative constitutional law of freedom of expression'. In: Ginsburg, Tom and Rosalind Dixon (eds.) Comparative Constitutional Law. Cheltenham: Edward Elgar. pp. 406-421.

Sunstein, Cass R. (1993): Democracy and the Problem of Free Speech. New York: Free Press.

Sunstein, Cass R. (2003): 'Free speech is not an absolute right'. In: Laura K. Egendorf (ed.) Should there be limits to free speech? San Diego: Greenhaven Press. pp. 8-12.

Svák, Ján (2011): Ochrana ludských práv v troch quäzkoch: 3. quäzok. Žilina: Eurokódex.

Svák, Ján and L’ubor Cibulka (2013): Ústavné právo Slovenskej republikey: Osobitná čast. Žilina: Eurokódex.

The Constitution of the First Czechoslovak Republic (1920). English translation accessible at: https://ia600401.us.archive.org/20/items/cu31924014118222/cu31924014118222.pdf

The Constitution of the Slovak Republic (Act No. 460/1992 Coll.).

Višňovský, Emil (2013): 'John Stuart Mill: sloboda a št’astie'. In: Novosád, František and Dagmar Smreková (eds.) Dejiny sociálneho a politickébo myslenia. Bratislava: Kalligram. pp. 425-446. 
Vojáček, Ladislav and Karel Schelle (2007): Právni dějiny na úz̨emi Slovenska. Ostrava: Key Publishing.

Warburton, Nigel (2009): Free Speech: A Very Short Introduction. Oxford: Oxford University Press.

Wilfling, Peter and Eva Kováčechová (2011): Sloboda prejavu a žaloby na ochranu dobrej povesti. Pezinok: Via Iuris. 